\title{
Pelatihan Pembuatan Media Informasi untuk Pamong Belajar di SKB Cerme Gresik
}

\author{
Udik Pudjianto ${ }^{1}$, Nia Saurina ${ }^{2}$, Anang Kukuh Adisusilo ${ }^{3}$, Firman $\mathrm{Hadi}^{4}$, \\ Emmy Wahyuningtyas ${ }^{5}$, Shofiya Syidada ${ }^{6}$ \\ ${ }^{1}$ Balai Pengembangan Pendidikan Anak Usia Dini dan Pendidikan Masyarakat \\ (BPPAUD \& DIKMAS) \\ ${ }^{1}$ udik.its@gmail.com \\ 2,3,4,5,6 Program Studi Teknik Informatika, Universitas Wijaya Kusuma Surabaya \\ 2niasaurina@gmail.com, ${ }^{3}$ anang@anang65.web.id, ${ }^{4}$ firmanp83@gamil.com, \\ 5emmycakep@gmail.com, ${ }^{6}$ cpya12@gmail.com
}

\begin{abstract}
Unit Pelaksana Teknis (UPT) Satuan Pendidikan Non Formal (SPNF) Sanggar Kegiatan Belajar (SKB) Cerme - Gresik, known as SKB Cerme is non formal education which is under Balai Pengembangan Pendidikan Anak Usia Dini dan Pendidikan Masyarakat (BPPAUD \& DIKMAS) East Java Province, has programs such as Playgroup Tunas Cendekia, Kindergarten Cendekia, Packet B equivalent with SMP, Packet C equivalent with SMA, Packet C Dewasa age above 22 years old, sewing course.

Videoscribe is software which can be used for animation design easily, even for people who did not have computer education. Videoscribe has been develop in 2012 by sparkol (one of company in England). This activity gives training to made information media to pamong belajar using videoscribe.
\end{abstract}

Keywords: Non-formal education, SKB Cerme Gresik, Information media, Videoscribe

\begin{abstract}
ABSTRAK
Unit Pelaksana Teknis (UPT) Satuan Pendidikan Non Formal (SPNF) Sanggar Kegiatan Belajar (SKB) Cerme - Gresik, untuk selanjutnya ditulis SKB Cerme merupakan lembaga pendidikan non formal di bawah Balai Pengembangan Pendidikan Anak Usia Dini dan Pendidikan Masyarakat (BPPAUD \& DIKMAS) Propinsi Jawa Timur menyelenggarakan program seperti Kelompok Bermain Tunas Cendekia, Taman Kanak-Kanak Cendekia, Paket B Setara SMP, Paket C Setara SMA, Paket C Dewasa Usia 22 Tahun ke atas, Kursus Menjahit.

Videoscribe adalah software yang bisa digunakan dalam membuat desain animasi dengan sangat mudah, walaupun oleh orang yang tidak memiliki latar belakang Teknik Komputer sekalipun. Software ini dikembangkan pada tahun 2012 oleh sparkol (Salah satu perusahaan yang ada di Inggris). Kegiatan pengabdian kepada masyarakat ini memberikan pelatihan pembuatan media informasi kepada pamong belajar menggunakan videoscribe.
\end{abstract}

Kata Kunci: Pendidikan non-formal, SKB Cerme Gresik, Media informasi, Videoscribe

\section{PENDAHULUAN}

Pendidikan nonformal merupakan jalur pendidikan di luar jalur formal yang dilaksanakan sebagai salah satu implementasi dari pendidikan sepanjang hayat. Dalam amandemen UndangUndang Dasar 1945 pemerintah telah menjamin pendidikan bagi seluruh warga negara Indonesia seperti yang tertulis dalam pasal 31 ayat 1 yaitu "Setiap warga negara berhak mendapatkan pendidikan". Berbeda dengan pendidikan formal yang terbatas pada umur, pendidikan non formal tidak terbatas pada umur, artinya siapapun dapat mendapatkan pembelajaran. Pendidikan non formal dapat ditempuh dari mulai 0 tahun sampai lansia sehingga pendidikan non formal memperluas kesempatan bagi orang-orang yang tidak terjangkau pendidikan formal untuk dapat mengenyam pendidikan dengan belajar di jalur pendidikan non formal. Secara garis besar Pendidikan non formal dibagi menjadi tujuh ranah yakni meliputi pendidikan kecakapan hidup, pendidikan anak usia dini, pendidikan kepemudaan, pendidikan pemberdayaan perempuan, pendidikan keaksaraan, pendidikan keterampilan dan pelatihan kerja, dan pendidikan kesetaraan. 
Salah satu lembaga pemerintah yang berperan dalam penyelenggraan pendidikan non formal saat ini adalah Sanggar Kegiatan Belajar (SKB). Sebelumnya SK Mendikbud RI.Nomor 023/0/1997 menyebutkan bahwa "Tugas pokok SKB : melaksanakan pembuatan percontohan dan pengendalian mutu pelaksanaan program pendidikan luar sekolah pemuda dan olahraga berdasarkan kebijakan teknis direktur jenderal pendidikan luar sekolah pemuda dan olahraga". Dari SK tersebut dapat diartikan bahwa sebelumnya tugas pokok SKB melaksanakan program-program percontohan dan pengendalian mutu pelaksanaan program pendidikan non formal. Tetapi setelah diberlakukannya Undang-Undang Nomor 22 tahun 1999 tentang pemerintahan daerah dan diperbaharui dengan Undang-Undang nomor 32 tahun 2004 maka peran dan fungsi SKB berubah sesuai dengan karakteristik dan kebijakan pemerintah Kabupaten/kota masing-masing. Sebagai lembaga yang memiliki tugas pokok menyelenggarakan pendidikan non formal SKB diharapkan mampu mengakses banyak program pendidikan non formal, memiliki tanggung jawab menyelenggarakan program-program sesuai dengan kebutuhan masyarakat, tetapi keterbatasan yang dimiliki SKB menyebabkan lembaga tidak dapat sepenuhnya melaksanakan tugas maupun fungsinya. Beberapa kendala yang umumnya dialami oleh SKB dalam penyelenggaraan programnya seperti kendala tenaga ahli atau SDM, sarana prasarana maupun dana sehingga programnya belum dapat berjalan dengan optimal.

Unit Pelaksana Teknis (UPT) Satuan Pendidikan Non Formal (SPNF) Sanggar Kegiatan Belajar (SKB) Cerme - Gresik, untuk selanjutnya ditulis SKB Cerme merupakan lembaga pendidikan non formal di bawah Balai Pengembangan Pendidikan Anak Usia Dini dan Pendidikan Masyarakat (BPPAUD \& DIKMAS) Propinsi Jawa Timur menyelenggarakan program seperti Kelompok Bermain Tunas Cendekia, Taman Kanak-Kanak Cendekia, Paket B Setara SMP, Paket C Setara SMA, Paket C Dewasa Usia 22 Tahun ke atas, Kursus Menjahit, yang dapat dilihat pada Gambar 1.

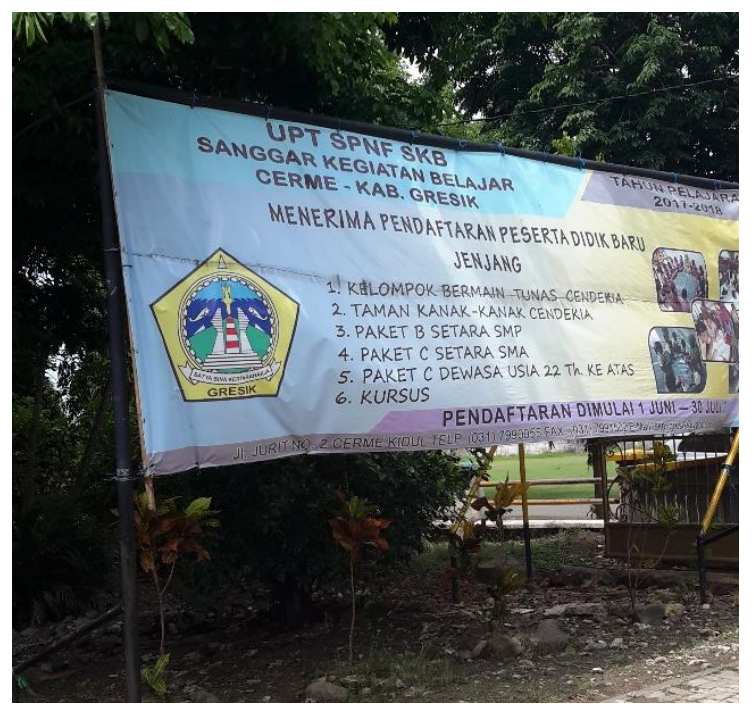

Gambar 1. Program SKB Cerme Gresik

Adanya berbagai faktor seperti dana, sarana prasrana, geografis, dan sasaran program yang tidak memungkinkan untuk menyelenggarakan program-programnya secara mandiri, maka dalam menyelenggarakan program-programnya SKB Cerme memerlukan media informasi yang interaktif sebagai sarana promosi dan sebagai sarana pembuatan materi dari instruktur atau pamong belajar kepada peserta didiknya. Tabel 1 memperlihatkan tenaga pamong belajar di SKB Cerme yang dimana dari 20 (dua puluh) orang, hanya 1 (satu) orang yang memiliki latar belakang Pendidikan Sarjana Teknik, padahal di Pendidikan Paket C Setara SMA memiliki mata pelajaran yang berbasis computer dengan peserta didik sebanyak 47 siswa. Selain itu pekerjaan untuk maintenance laboratorium komputer dan promosi berbasis web juga menjadi pekerjaan yang harus dilakukan oleh pamong belajar. 
Tabel 1. Daftar Pamong Belajar di SKB Cerme Gresik

\begin{tabular}{ll}
\hline No & Nama Pamong Belajar \\
\hline 1 & Jumangin, S.Pd \\
\hline 2 & Nuryati \\
\hline 3 & Muniroh, S.Pd. \\
\hline 4 & Hamimah, S.Pd. \\
\hline 5 & Fathur Rahman, S.Pd. \\
\hline 6 & Fathoni Amin, S.Pd. \\
\hline 8 & Hadi Taufiqur R, S.Pd. \\
\hline 9 & Imron, S.Pd. \\
\hline 10 & Siti Choriyah \\
\hline 11 & Dra. Nur Wakhidah \\
\hline 12 & Masruroh Anggraeni, S.Pd. \\
\hline 13 & Eridayana Ayuning P., A.Ma. \\
\hline 14 & Endang Hidayati, SE \\
\hline 15 & Haris Agustin, S.Pd. \\
\hline 16 & Hasan Basri, ST. \\
\hline 17 & Ari Sugiartini \\
\hline 18 & Lutfi Nurjanatin, S.Pd. \\
\hline 19 & Yanik Masfiana, S.Pd. \\
\hline 20 & Maria Dewi R, , S.Pd. \\
\hline
\end{tabular}

Videoscribe adalah software yang bisa digunakan dalam membuat desain animasi dengan sangat mudah, walaupun oleh orang yang tidak memiliki latar belakang Teknik Komputer sekalipun. Software ini dikembangkan pada tahun 2012 oleh sparkol ( Salah satu perusahaan yang ada di Inggris ). Kegiatan pengabdian kepada masyarakat ini memberikan pelatihan pembuatan media informasi kepada pamong belajar menggunakan videoscribe.

\section{METODE PELAKSANAAN}

Metode pelaksanaan atau tahapan yang dilakukan dalam program pengabdian masyarakat ini ditunjukkan pada Gambar 1

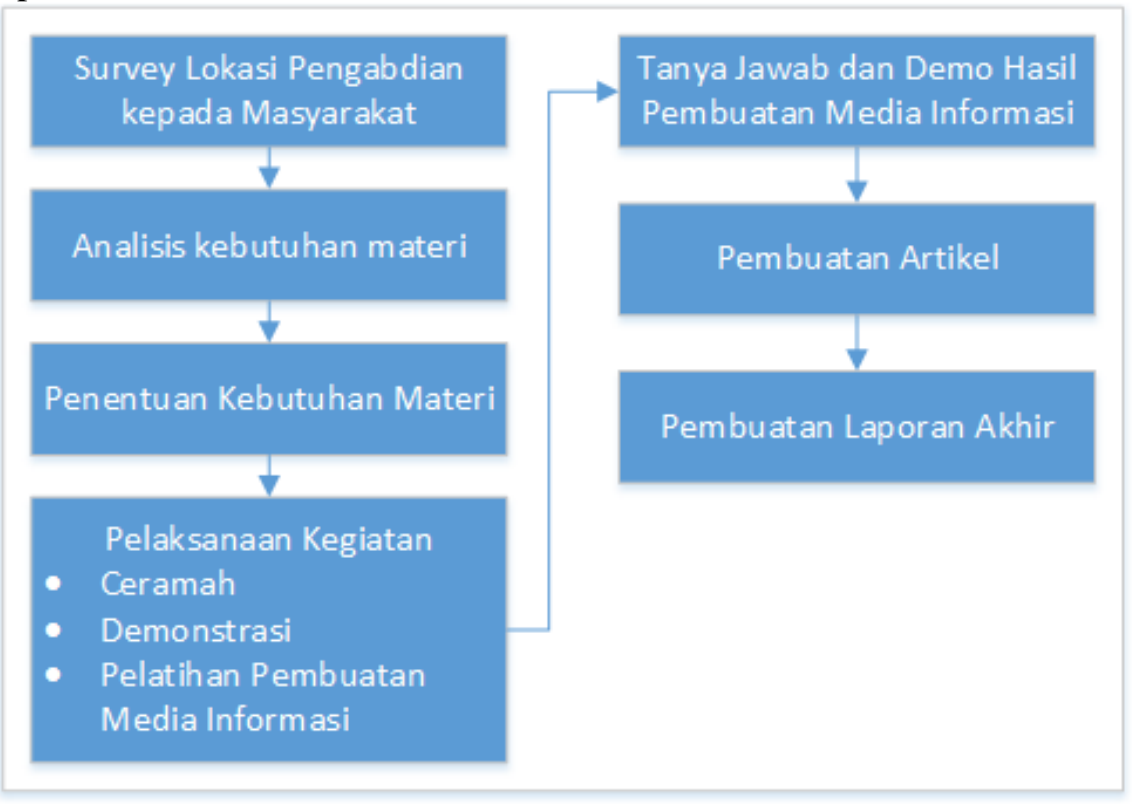

Gambar 2. Metode Pelaksanaan 


\section{Metode pelaksanaan}

Beberapa tahapan pelaksanaan pengabdian kepada masyarakat dapat diurutkan sebagai berikut, yaitu :

1. Survey Lokasi Pengabdian Kepada Masyarakat

Beberapa dosen Program Studi Informatika menemui Kepala SKB Cerme - Gresik, menyampaikan tujuan kedatangan ke lokasi dan menyerahkan surat pengantar dari Fakultas Teknik Universitas Wijaya Kusuma Surabaya kepada Kepala SKB Cerme dan mendiskusikan mengenai materi yang diberikan, hari dan tanggal pelaksanaan pengabdian kepada masyarakat. Selain itu meminta tanda terima penyampaian surat pengantar dari Tata Usaha SKB Cerme sebagai bukti bahwa kelompok pengabdian kepada masyarakat sudah melakukan kunjungan.

2. Analisis Kebutuhan Materi

Membicarakan pendidikan nonformal bukan berarti hanya membahas pendidikan nonformal sebagai sebuah pendidikan alternatif bagi masyarakat, akan tetapi berbicara pendidikan nonformal adalah berbicara tentang konsep, teori dan kaidah-kaidah pendidikan yang utuh yang sesuai dengan kondisi dan kebutuhan kehidupan masyarakat. Karena pendidikan nonformal sebuah layanan pendidikan yang tidak dibatasi dengan waktu, usia, jenis kelamin, ras (suku, keturunan), kondisi sosial budaya, ekonomi, agama dll.

Permasalahan yang dihadapi SKB Cerme adalah kurangnya promosi profile lembaga dalam bentuk video, sehingga masyarakat mengenal Pendidikan non formal sebagai lembaga Pendidikan, bahkan para alumni peserta didik dari SKB Cerme juga tetap dapat melanjutkan Pendidikan ke jenjang Perguruan Tinggi. Selain itu para pamong belajar perlu meningkatkan kemampuan dalam membuat materi pembelajaran yang lebih menarik kepada peserta didiknya.

3. Penentuan Kebutuhan Materi

Mengingat pamong belajar yang memiliki latar belakang Pendidikan Teknik Komputer berjumlah 1 orang, maka diperlukan sebuah software untuk membuat media informasi yang mudah dan menarik. Videoscribe mirip dengan Ms. Power point, hanya saja template yang diberikan Videoscribe jauh lebih menarik dan mudah dalam menggabungkan antara gambar, suara dan animasi.

4. Pelaksanaan Kegiatan

- Ceramah digunakan untuk menyampaikan pengetahuan secara umum tentang media informasi untuk kebutuhan promosi dan kegiatan belajar mengajar.

- Demontrasi digunakan untuk memberikan keterampilan langsung mengenai proses pembuatan media informasi dengan Videoscribe

- Pelatihan pembuatan media informasi bertujuan membuat media informasi menggunakan template yang telah disediakan di Videoscribe

5. Tanya Jawab dan Demo Hasil Pembuatan Media Informasi

- Tanya jawab digunakan untuk melengkapi hal-hal yang belum terakomodasi pada saat pelaksanaan kegiatan. Selain itu sesi tanya jawab dapat menjadi jembatan komunikasi antara pemateri dan pamong belajar sebagai penerima materi.

- Demo Hasil pembuatan Media Informasi bertujuan untuk merepresentasikan hasil pembuatan media informasi dari pamong belajar

6. Pembuatan Artikel

Pembuatan artikel dilakukan setelah pelaksanaan kegiatan, yang bertujuan untuk mempublish hasil pelaksanaan kegiatan pengabdian kepada masyarakat.

7. Pembuatan Laporan Akhir

Pembuatan Laporan akhir merupakan bagian terakhir dari dokumentasi kegiatan. 


\section{HASIL DAN PEMBAHASAN}

Pembuatan Media Informasi dengan Videoscribe

Tabel 2. Prosentase hasil kuesioner terhadap Pembuatan Media Informasi dengan Videoscribe

\begin{tabular}{cccc}
\hline No & Kriteria & Jumlah Responden & Persentase \\
\hline 1 & Menarik & 12 & $60 \%$ \\
\hline 2 & Cukup & 6 & $30 \%$ \\
\hline 3 & Tidak Menarik & 2 & $10 \%$ \\
\hline & Total & 20 & $100 \%$ \\
\hline
\end{tabular}

\section{KESIMPULAN}

Program Pengabdian Kepada Masyarakat pamong belajar SKB Cerme - Gresik telah selesai dilakukan dengan menghasilkan :

1. Media Promosi

2. Media Informasi

3. Hasil kuesioner menunjukkan bahwa kriteria Menarik mendapatkan prosentase tertinggi sebesar $60 \%$

Hasil aplikasi perlu untuk diterapkan secara berkelanjutan pada SKB Cerme. Aplikasi dapat dikembangkan dengan menggunakan template online dari Videoscribe yang jauh lebih banyak variasnya bila dibandingkan versi offline, sehingga aplikasi dapat tepat guna dan bermanfaat khususnya untuk pembuatan media informasi.

\section{UCAPAN TERIMA KASIH}

Kami sampaikan terima kasih kepada LPPM Universitas Wijaya Kusuma Surabaya yang telah membiayai kegiatan pengabdian masyarakat ini. Kami haturkan terima kasih pula pada UPT SPNF SKB Cerme Gresik atas kesempatan untuk melakukan kegiatan pengabdian kepada masyarakat

\section{DAFTAR PUSTAKA}

Admaja, Ketut. (1993). Teknik Identifikasi Kebutuhan dan Sumber Belajar PLS. Surabaya : University Press IKIP Surabaya

Arif S, Sadiman, dkk. (2005). Media Pendidikan, Pengertian, Pengembangan, dan Pemanfaatannya. Jakarta: PT. Raja Grafindo Persada.

Binanto, I. (2010). Multimedia Digital Dasar Teori dan Pengembangannnya. Yogyakarta: Andi.

Hery Nuryanto. (2002). Sejarah Perkembangan Teknologi dan Komunikasi. PT. Balai Pustaka. Jakarta.

Jack R, Fraenkel Dan Norman E, Wallen. (2009). How to Design and Evaluate Research in Education. New York. The McGraw-Hill Companies, Inc. Kartadinata,

Kementerian Pendidikan dan Kebudayaan Republik Indonesia Nomor: 023/0/1997 tanggal 20 Pebruari 1997 tentang Susunan Organisasi dan Tata Kerja SKB

Sihombing, Umberto. (2000). Pendidikan Luar Sekolah Kini dan Masa Depan. Jakarta: PD Mahkota.

Soelaman Joesoef, (1992), Konsep Dasar Pendidikan non formal, Penerbit: Bumi Aksara, Jakarta. Sudjana, Djudju. (2004). Pendidikan Non Formal. Bandung: Falah Production.

2004. Manajemen Program Pendidikan : Untuk Pendidikan Nonformal dan Pengembangan Sumber Daya Manusia. Bandung: Falah Production.

Sunaryo. (2009). Mewujudkan Masyarakat Pembelajar, Bandung: Widya Aksara Press

Undang-undang No. 32 Tahun 2004 tentang Pemerintahan Daerah

Undang-Undang Dasar Tahun 1945 Pasal 31 Ayat 1 Tentang Hak dan Kewajiban Warga Negara

Videoscribe. https://www.videoscribe.co/en/ diakses pada tanggal 31 Oktober 2017 
JPP IPTEK, Mei 2018, Vol. 2, No. 1

Halaman ini sengaja dikosongkan 